\title{
PENGARUH KUALITAS LAYANAN DAN PENGALAMAN TERHADAP KEPUASAN SERTA KEPERCAYAAN WISATAWAN (STUDI PADA WISATAWAN YANG BERKUNJUNG PADA OBYEK WISATA TELAGA MENJER DI WONOSOBO)
}

\author{
Gandhi Satria Wicaksana \\ Jurusan Ilmu Administrasi Bisnis \\ Universitas Pembangunan Nasional "Veteran" Yogyakarta \\ e-mail : gandhi_satria@yahoo.com \\ Eny Endah Pujiastuti \\ Staf Pengajar Jurusan Ilmu Administrasi Bisnis \\ Universitas Pembangunan Nasional "Veteran" Yogyakarta \\ e-mail : eny_endah@yahoo.co.id \\ Suratna \\ Staf Pengajar Jurusan Ilmu Administrasi Bisnis \\ Universitas Pembangunan Nasional "Veteran" Yogyakarta \\ e-mail : suratno66@yahoo.com
}

\begin{abstract}
The tourism industry is growing rapidly so research in tourism is also growing rapidly. This study aims to examine the tourist behavior intention in the future, especially post visiting the behavior intention. The problem raised is). Does service quality have a significant effect on tourist satisfaction?. 2. Does the tourist experience have a significant effect on tourist satisfaction?. 3. Does service quality have a significant effect on tourist trust?. 4. Do tourist experiences have a significant effect on tourist trust?. Does tourist satisfaction have a significant effect on tourist trust? The research was carried out at tourist sites, namely the lake of the Wonosobo trail. The sample used was Telaga Menjer visitors who first visited Telaga Menjer tourism object. The number of samples is 115 respondents. The method used is systematic random sampling with analysis techniques using path analysis. The results of the study show that there is a significant effect of Service Quality on Tourist Satisfaction, There is a significant influence of Tourist Experience on Tourist Satisfaction, There is a significant effect of Service Quality on Tourist Trust, There is a significant influence of Tourist Experience on Tourist Trust, There is a significant influence Satisfaction Tourists towards Tourist Trust.
\end{abstract}

\begin{abstract}
ABSTRAK
Industri pariwisata berkembang pesat sehingga penelitian dalam pariwisata juga berkembang pesat. Penelitian ini bertujuan untuk menguji niat perilaku wisatawan di masa depan, terutama pasca kunjungan niat perilaku. Masalah yang diangkat adalah). Apakah kualitas layanan berpengaruh signifikan terhadap kepuasan wisatawan? 2. Apakah pengalaman wisata berpengaruh signifikan terhadap kepuasan wisatawan? 3. Apakah kualitas layanan berpengaruh signifikan terhadap kepercayaan wisatawan? 4. Apakah pengalaman wisata berpengaruh signifikan terhadap kepercayaan wisatawan? Apakah kepuasan wisatawan berpengaruh signifikan terhadap kepercayaan wisatawan? Penelitian ini dilakukan di lokasi wisata, yaitu danau jejak Wonosobo. Sampel yang digunakan adalah pengunjung Telaga
\end{abstract}


Menjer yang pertama kali mengunjungi objek wisata Telaga Menjer. Jumlah sampel adalah 115 responden. Metode yang digunakan adalah sampling acak sistematis dengan teknik analisis menggunakan analisis jalur. Hasil penelitian menunjukkan bahwa terdapat pengaruh yang signifikan antara Kualitas Layanan terhadap Kepuasan Wisatawan, Ada pengaruh yang signifikan dari Pengalaman Wisatawan terhadap Kepuasan Wisatawan, Ada pengaruh yang signifikan Kualitas Layanan terhadap Kepercayaan Wisatawan, Ada pengaruh yang signifikan dari Wisatawan Pengalaman di Tourist Trust, Ada pengaruh yang signifikan Kepuasan Wisatawan terhadap Tourist Trust.

Kata Kunci : Pariwisata, Niat Perilaku, pengalaman, kepercayaan diri, Nilai Persepsi

\section{PENDAHULUAN}

Pariwisata adalah suatu kegiatan multidimensi dan multidisiplin yang dapat memberikan dampak positif dan negatif bagi suatu destinasi (negara) yang diminati oleh wisatawan. Kegiatan wisata tersebut hanya bisa tercipta jika didukung oleh kebijakan suatu negara dalam menyediakan segala aspek yang terkait dengan atraksi, aksesibilitas, dan amenitas termasuk faktor keamanan (Judisseno, 2017).

Pariwisata merupakan salah satu sektor yang diandalkan pemerintah untuk memperoleh devisa dari penghasilan non migas. Peranan pariwisata dalam pembangunan nasional, di samping sebagai sumber perolehan devisa juga banyak memberikan sumbangan terhadap bidang-bidang lainnya, diantaranya menciptakan dan memperluas lapangan usaha, meningkatkan pendapatan masyarakat dan pemerintah, mendorong pelestarian lingkungan hidup dan budaya bangsa, memperkokoh persatuan dan kesatuan bangsa dan lain sebagainya (Karyono, 2008).

Pariwisata baik jenis pariwisata domestik maupun pariwisata internasional di dalamnya mengandung berbagai aspek, yaitu aspek sosiologis, psikologis, hukum, ekonomi, ekologis, dan mungkin aspek lainnya. Peran pariwisata begitu pentingnya dalam pembangunan ekonomi dunia sehingga pariwisata sering dijuluki sebagai passport to development, maka tidak berlebihan bila hampir semua negara saat ini saling berkompetisi menjual keindahan alamnya, keunikan budayanya, dan keramah-tamahan penduduknya ke berbagai negara yang menjadi pasar potensialnya.

Kepercayaan sebagai suatu kondisi ketika salah satu pihak yang terlibat dalam proses pertukaran yakin dengan keandalan dan integritas pihak yang lain (Suhardi,2006). Definisi tersebut menjelaskan bahwa kepercayaan adalah kesediaan atau kerelaan untuk bersandar pada rekan yang terlibat dalam pertukaran yang diyakini. Kerelaan merupakan hasil dari sebuah keyakinan bahwa pihak yang terlibat dalam pertukaran akan memberikan kualitas yang konsisten, kejujuran, bertanggung jawab, ringan tangan, dan berhati baik. Keyakinan ini menciptakan hubungan yang dekat antara pihak yang terlibat pertukaran

$$
\text { Kepercayaan menurut Suhardi }
$$
(2006) didefinisikan sebagai prepsepsi akan kehandalan daei sudut pandang konsumen didasarkan pada pengalaman, atau lebih pada urut-urutan transaksi atau interaksi yang dicirikan oleh terpenuhinya harapan akan kinerja produk dan kepuasan. Ciri utama terbentuknya kepercayaan adalah presepsi positif yang terbentuk dari pengalaman. Kepercayaan menurut Darsono (2008) adalah sebagai kesediaan (willingness) individu untuk menggantungkan dirinya pada pihak lain yang terlibat dalam pertukaran karena individu mempunyai keyakinan 
(confidence) kepada pihak lain tersebut Sedangkan kepercayaan wisatawan terhadap objek wisata merupakan aset terbesar untuk mencapai loyalitas wisatawan agar mau berkunjung lagi.

Kepercayan dipercaya menjadi faktor yang fundamental bagi sebuah kesuksesan dalam membangun hubungan baik dan hal tersebut berhasil dicapai manakala suatu pihak percaya dan nyaman dalam sebuah hubungan yang dilandasi oleh sebuah integritas (Morgan dan Hunt, 1994). Kepercayaan wisata dapat dipengaruhi oleh pengalaman(Pujiastuti, Nimran, Suharyono dan Kusumawati, 2017a), kualitas layanan (Canny, 2013) dan kepuasan wisatawan ketika berkunjung ke obyek wisata tersebut (Pujiastuti, Nimran, Suharyono dan Kusumawati, 2017b).

Kepuasan menjadi faktor yang paling penting untuk diperhatikan oleh pengelola tempat wisata terhadap wisatawan. Hal ini tidak dapat dipungkiri bahwa wisatawan memiliki tujuan utama mendapatkan kepuasan dalam mendapatkan pelayanan. Kepuasan menurut Kotler (2009) adalah mencerminkan penilaian seseorang tentang kinerja produk anggapannya (hasil) dalam kaitannya dengan ekspektasi. Jika kinerja produk tidak memenuhi ekspektasi, wisatawan tersebut tidak puas dan kecewa. Kertajaya (2007), mengemukakan bahwa wisatawan yang puas pasti akan mempunyai tingkat kepercayaan yang yang tinggi terhadap produk dibandingkan dengan wisatawan yang tidak puas. Wisatawan dalam hal ini adalah wisatawan, sedangkan produk adalah obyek wisata, yang didalamnya terdapat kualitas layanan. Kepuasan wisatawan terhadap obyek wisata dapat dipengaruhi oleh banyak faktor. Kepuasan dapat dipengaruhi oleh kualitas layanan (Canny, 2013) dan juga oleh pengalaman wisatawan (Ridwan, et al, 2015).

Kualitas pelayanan menurut Tjiptono (2011) adalah merupakan kondisi dinamis yang berhubungan dengan produk, jasa, manusia, proses, dan lingkungan yang memenuhi atau melebihi harapan. Juga diartikan sebagai sesuatu yang berhubungan dengan terpenuhinya harapan/kebutuhan wisatawan, dimana pelayanan dikatakan berkualitas apabila dapat menyediakan produk dan jasa (pelayanan) sesuai dengan kebutuhan dan harapan wisatawan. Kualitas layanan di sebuah obyek wisata sangat penting diperhatikan untuk memberikan kepuasan terhadap wisatawan. Kualitas layanan bisa dalam bentuk fasilitas dan suasana yang ditawarkan oleh obyek wisata kepada wisatawan. Beberapa diantaranya adalah pengelolaan, kebersihan tempat, kemudahan akses, dan fasilitas pendukung yang disedikan di obyek wisata.

Pengalaman menurut Kelly (2017), adalah persepsi yang terbentuk selama kejadian, yang mana aspek psikologi terhubung dengan kejadian yang terjadi. Pengalaman terbentuk ketika konsumen menikmati nilai guna dari produk. Pengalaman konsumen menurut Meyer dan Schwager (2007), adalah tanggapan konsumen secara internal dan subyektif sebagai akibat dari interaksi secara langsung maupun tidak langsung dengan produk. Pengalaman wisatawan merupakan merupakan salah satu faktor yang mempengaruhi citra destinasi pariwisata, sehingga semakin baik pengalaman wisatawan maka akan memunculkan kesan-kesan yang baik dan selanjutnya akan menghasilkan citra yang positif. Idealnya, suatu kawasan wisata seharusnya dapat menyajikan pengalaman yang mengesankan bagi wisatawan, bahkan zero complain sehingga akan semakin mendukung citra positif suatu obyek wisata. Semakin baik pengalaman wisatawan, makin semakin tinggi pula tingkat kepuasan dan kepercayaan para wisatawan terhadap obyek wisata tersebut

Telaga Menjer adalah salah satu obyek wisata yang berlokasi di Kabupaten Wonosobo, Jawa Tengah. Telaga Menjer 
menjadi salah satu obyek wisata yang terkenal di Wonosobo. Namun demikian, ada beberapa pemasalahan yang terdapat di obyek wisata Telaga Menjer. Berdasarkan wawancara yang dilakukan pada tanggal 1 Agustus 2018 sebagai aktivitas observasi sebelum penelitian dengan salah satu pengunjung Telaga Menjer didapatkan beberapa permasalahan di obyek wisata Telaga Menjer, yakni; kebersihan obyek wisata tidak terlalu diperhatikan oleh pengelola, keamanan kurang terjamin, dan tidak adanya sarana toilet. Masalah-masalah tersebut bisa jadi akan menyebabkan menurunnya tingkat kepuasan dan kepercayaan wisatawan di Telaga Menjer, sehingga mereka tidak akan berkunjung lagi.

Berdasarkan uraian latar belakang di atas, maka rumusan masalah dalam penelitian ini adalah sebagai berikut:

1. Apakah kualitas layanan berpengaruh signifikan terhadap kepuasan wisatawan?

2. Apakah pengalaman wisatawan berpengaruh signifikan terhadap kepuasan wisatawan?

3. Apakah kualitas layanan berpengaruh signifikan terhadap kepercayaan wisatawan?

4. Apakah pengalaman wisatawan berpengaruh signifikan terhadap kepercayaan wisatawan?

5. Apakah kepuasan wisatawan berpengaruh signifikan terhadap kepercayaan wisatawan?

Service quality is an abstract concept, and in operationalizing it, Parasuraman, Zeithaml and Berry (1988) have identified five dimensions of service quality. They are Tangibles (appearance of physical facilities, personnel and materials), Reliability (dependable and accurate performance), Responsiveness (willingness to help customers and the romptness of service), Assurance (knowledge and courtesy of employees) and Empathy (caring and individualized attention to customers). Grönroos (1984) defines service quality as "the outcome of an evaluation process where the consumer compares his expectations with the service he perceived he has received". Definitions of quality have included: a) satisfying or delighting the customer or exceeding expectations; b) product of service features that satisfy stated or implied needs; c).conformance to clearly specified requirements; and d) fitness for use, whereby the product meets the customers needs and is free of deficiencies (Chelladurai and Chang, 2000)

Pengalaman menurut Hirschman and Holbrook (1982) adalah those facets of consumer behaviour that relate to the multi-sensory, fantasy, and emotive aspects of product use. Kelly (1987) berpendapat bahwa pengalaman adalah persepsi selama kegiatan, semacam proses psikologis yang terhubung dengan acara. Poulsson and Kale (2004) define it as an engaging act of cocreation between a provider and a consumer where in the consumer perceives value in the encounter and in the subsequent memory of that encounter. Gentile, Spiller, and Noci (2007) state that customer experience comes from a series of relationships between the customer and the item or service, the company, or part of the company to produce a response.

In tourism research, tourists' experience during trips has mainly been concerned with visiting, seeing, learning, enjoying, and living different lifestyles (Stamboulis and Skayannis, 2003). Reviewing current literature, experience has played a main construct in travel and tourism (Oh,Fiore, and Jeoung, 2007). Tourism experience can refer to the events that lead to positive or negative emotions, which in turn contribute to creating memories (Oh et al., 2007).

In literatures about tourism, consumer satisfaction is evaluation based on interaction with service providers and used by customers to predict future 
experience (Crosby et al., 1990). Traveler satisfaction, according to Baker and Crompton (2000), is emotional state of travelers after experience. It means satisfaction is traveler's reaction after having experience or visiting tourist destination. Traveler's satisfaction is real experience after traveling which is derived from psychological state resulted from individual experience to reach certain toruism spot.

Trust is believed to be a fundamental component of building successful relationships and it exists when one party believes and has confidence in the exchange partner's reliability and integrity (Morgan and Hunt, 1994). Trust is an essential element to develop sustainable relationship between tourist village managers and customer or market share (Urban et al., 2000). A study conducted by Arnett and Badrinarayanan (2005) suggested that the factors that influence the success of relationship marketing is the quality of the relationship, although the three factors that have consistently been identified as a determinant of success in marketing relationship are trust, commitment, and communication. Trust is deemed as attitudes or beliefs or as behavioral intention (Kim, Chung, and Lee, 2011). Real trust is an attitude of a customer, addressed to company as a partner, who will take measures to produce positive results for customers (Albrubaiee and Al-Nazer, 2010). Chang (2014) states customer trust is composed of affective and cognitive trust.

Pengaruh kualitas layanan terhadap kepuasan wisatawan pernah diteliti oleh Canny (2013) dimana hasil penelitiannya menunjukkan bahwa kualitas layanan memiliki hubungan yang positif signifikam terhadap kepuasan wisatawan.

$\mathrm{H}_{1}$ : Ada pengaruh yang signifikan Kualitas Layanan terhadap Kepuasan Wisatawan

Pengaruh pengalaman wisatawan terhadap kepuasan wisatawan sebelumnya pernah diteliti oleh Riduan, et al (2015) dimana hasil penelitiannya menemukan bahwa pengalaman wisatawan berpengaruh signifikan terhadap kepuasan wisatawan.

$\mathrm{H}_{2}$ : Ada pengaruh yang signifikan Pengalaman Wisatawan terhadap Kepuasan Wisatawan

Pengaruh kualitas layanan terhadap kepercayaan wisatawan sebelumnya pernah diteliti oleh Kartikasari, dkk (2014) yang menemukan bahwa kualitas layanan berpengaruh positif terhadap kepercayaan wisatawan.

$\mathrm{H}_{3}$ : Ada pengaruh yang signifikan Kualitas Layanan terhadap Kepercayaan Wisatawan

Pengaruh pengalaman wisatawan terhadap kepercayaan wisatawan sebelumnya pernah diteliti oleh Pujiastuti, et al (2017) yang menemukan bahwa pengalaman wisatawan berpengaruh positif terhadap kepercayaan wisatawan.

$\mathrm{H}_{4}$ : Ada pengaruh yang siginifikan Pengalaman Wisatawan terhadap Kepercayaan Wisatawan.

Pengaruh kepuasan wisatawan terhadap kepercayaan wisatawan sebelumnya pernah diteliti oleh Pujiastuti, et al (2017b) yang menemukan bahwa kepuasan wisatawan berpengaruh positif terhadap kepercayaan wisatawan.

$\mathrm{H}_{5}$ : Ada pengaruh yang signifikan Kepuasan Wisatawan terhadap Kepercayaan Wisatawan.

\section{METODE}


Tipe penelitian yang digunakan dalam penelitian ini adalah tipe penelitian explanatory yang berupaya untuk menjelaskan ada tidaknya pengaruh suatu variabel dengan variabel lainnya. Sampel dalam penelitian ini adalah sebagian dari pengunjung Telaga Menjer yang baru pertama kali mengunjungi obyek wisata Telaga Menjer. Ukuran sampel yang didasarkan atas pertimbangan teknik analisis yang dipergunakan dalam penelitian Matchin dan Campbel (1989). Adapun jumlah sampel yang dipergunakan sebanyak 115 responden. Metode yang digunakan adalah systematic random

\section{ANALISIS DAN PEMBAHASAN}

Berdasarkan hasil regresi sederhana dapat diketahui hasil penelitian sebagai berikut :

1. Pengaruh Kualitas Layanan Terhadap Kepuasan Wisatawan

Hasil perhitungan regresi diketahui nilai sig sebesar 0,000 . Hal ini menunjukkan bahwa nilai sig < 0,05 , sehingga variabel kualitas layanan mempunyai pengaruh yang signifikan terhadap kepuasan wisatawan. Dengan demikian hasil uji secara parsial pada hipotesis pertama yang menyatakan "adanya pengaruh yang siginifikan kualitas layanan terhadap kepuasan wisatawan" Hipotesis ini dapat diterima dan terbukti. koefisien determinasi sebesar 0.397, maka dapat diartikan bahwa $39,7 \%$ kepuasan wisatawan (Z) dapat dijelaskan oleh variabel bebas yaitu kualitas layanan, sedangkan sisanya sebesar $100 \%-39,7 \%=60,3 \%$ dipengaruhi oleh variabel lain yang tidak termasuk dalam model penelitian ini.

2. Pengaruh Pengalaman Wisatawan Terhadap Kepuasan Wisatawan sampling (pada populasi yang tak terbatas). Alat ukur yang digunakan dalam kuesioner adalah menggunakan Skala Likert.

Teknik analisis yang digunakan dalam penelitian ini adalah analisis jalur (path analysis). Analisis jalur digunakan untuk menganalisis pola hubungan antar variabel dengan tujuan untuk mengetahui pengaruh langsung maupun tidak langsung seperangkat variabel bebas (eksogen) terhadap variabel terikat (endogen). Analisis jalur merupakan perluasan dari analisis regresi linear sederhana (Ghozali, 2011).
Hasil perhitungan regresi diketahui nilai sig sebesar 0,000 . Hal ini menunjukkan nilai sig $<0,05$, sehingga variabel pengalaman wisatawan mempunyai pengaruh yang signifikan terhadap kepuasan wisatawan. Dengan demikian hasil uji secara parsial pada hipotesis kedua yang menyatakan "adanya pengaruh yang siginifikan pengalaman wisatawan terhadap kepuasan wisatawan" Hipotesis ini dapat diterima dan terbukti. koefisien determinasi sebesar 0.535, maka dapat diartikan bahwa 53,5\% kepuasan wisatawan (Z) dapat dijelaskan oleh variabel bebas yaitu pengalaman wisatawan, sedangkan sisanya sebesar $100 \%-53,5 \%=46,5 \%$ dipengaruhi oleh variabel lain yang tidak termasuk dalam model penelitian ini.

3. Pengaruh Kualitas Layanan Terhadap Kepercayaan Wisatawan

$$
\text { Hasil perhitungan regresi }
$$
diketahui nilai sig sebesar 0,000. Hal ini menunjukkan bahwa t-hitung $>\mathrm{t}$ tabel $(1,98)$ dan nilai sig $<0,05$, sehingga variabel kualitas layanan 
mempunyai pengaruh yang signifikan terhadap kepercayaan wisatawan. Dengan demikian hasil uji secara parsial pada hipotesis ketiga yang menyatakan "adanya pengaruh yang siginifikan kualitas layanan terhadap kepercayaan wisatawan" Hipotesis ini dapat diterima dan terbukti. Koefisien determinasi sebesar 0.451, maka dapat diartikan bahwa 45,1\% kepercayaan wisatawan (Y) dapat dijelaskan oleh variabel bebas yaitu kualitas layanan, sedangkan sisanya sebesar $100 \%$ $45,1 \%=54,9 \%$ dipengaruhi oleh variabel lain yang tidak termasuk dalam model penelitian ini.

4. Pengaruh Pengalaman Wisatawan Terhadap Kepercayaan Wisatawan

Hasil perhitungan regresi diketahui nilai sig sebesar 0,000. Hal ini menunjukkan bahwa t-hitung $>\mathrm{t}$ tabel $(1,98)$ dan nilai sig $<0,05$, sehingga variabel pengalaman wisatawan mempunyai pengaruh yang signifikan terhadap kepercayaan wisatawan. Dengan demikian hasil uji secara parsial pada hipotesis keempat yang menyatakan "adanya pengaruh yang siginifikan pengalaman wisatawan terhadap kepercayaan wisatawan" Hipotesis ini dapat diterima dan terbukti. Koefisien determinasi sebesar 0.667, maka dapat diartikan bahwa $66,7 \%$ kepercayaan wisatawan (Y) dapat dijelaskan oleh variabel bebas yaitu pengalaman wisatawan, sedangkan sisanya sebesar $100 \%$ $66,7 \%=33,3 \%$ dipengaruhi oleh variabel lain yang tidak termasuk dalam model penelitian ini.

5. Pengaruh Kepuasan Wisatawan Terhadap Kepercayaan Wisatawan

Hasil perhitungan regresi diketahui nilai sig sebesar 0,000 . Hal ini menunjukkan bahwa t-hitung $>\mathrm{t}-$ tabel $(1,98)$ dan nilai sig $<0,05$, sehingga variabel kepuasan wisatawan mempunyai pengaruh yang signifikan terhadap kepercayaan wisatawan. Dengan demikian hasil uji secara parsial pada hipotesis kelima yang menyatakan "adanya pengaruh yang signifikan kepuasan wisatawan terhadap kepercayaan wisatawan" Hipotesis ini dapat diterima dan terbukti.

\section{Gambar 1}

\section{Model Hasil Penelitian}

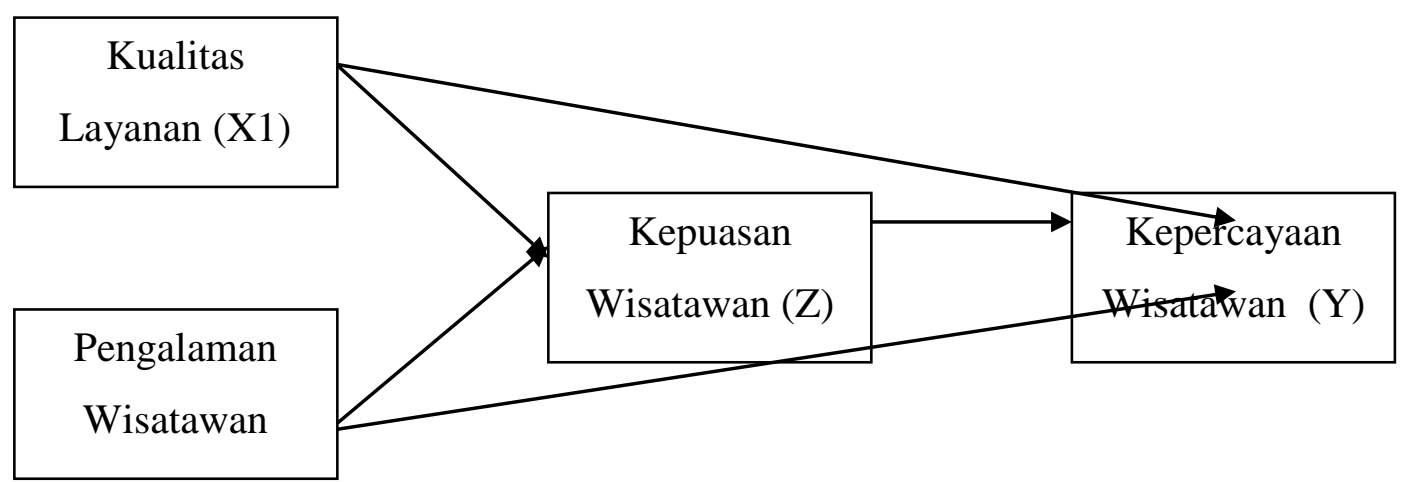

Berdasarkan hasil perhitungan sobel dapat diketahui nilai t-hitung sebesar 7,5455, karena nilai t-hitung $>$ t-tabel $(7,5455>1,98)$ dengan tingkat signifikansi 5\% maka membuktikan bahwa kepuasan wisatawan mampu memediasi hubungan pengaruh kualitas layanan terhadap kepercayaan wisatawan. Hal ini berarti terdapat hubungan tidak lamgsung antara kualitas layanan terhadap kepercayaan wisatawan.Kualitas layanan 
mempengaruhi kepercayaan wisatawan dengan melalui kepuasan.

Berdasarkan hasil perhitungan sobel didapat nilai t-hitung sebesar 7,288, karena nilai t-hitung > t-tabel $(7,288>1,98)$ dengan tingkat signifikansi $5 \%$ maka membuktikan bahwa kepuasan wisatawan mampu memediasi hubungan pengaruh 1. Pengaruh Kualitas LayananTerhadap Kepuasan Wisatawan

Hasil pengujian hipotesis, ditemukan adanya bukti yang menunjukkan bahwa terdapat pengaruh yang signifikan kualitas layanan terhadap kepuasan wisatawan. Hal ini dapat dibuktikan dengan nilai signifikan yang diperoleh dibawah $\alpha=$ 0,05 yaitu 0,000 . Oleh karena itu hipotesis 1 yang berbunyi ada pengaruh yang signifikan kualitas layanan terhadap kepuasan wisatawan terbukti dan diterima.

Penelitian ini sesuai dengan pendapat Lupiyoadi (2001) yang mengatakan bahwa pelanggan merasa puas bila mendapatkan pelayanan yang baik atau yang sesuai dengan harapannya. Selain itu, hasil penelitian ini sama dengan penelitian yang dilakukan oleh Canny (2013) dimana hasil penelitiannya menunjukkan bahwa kualitas layanan memiliki hubungan yang signifikam terhadap kepuasan wisatawan.

Dapat dismpulkan bahwa, suatu pelayanan dikatakan berkualitas apabila dapat menyediakan jasa sesuai dengan kebutuhan dan harapan pengunjung. Sehingga untuk memberikan kualitas layanan harus dimulai dari kebutuhan wisatawan dan harapannya, apabila sesuai atau melampaui harapan maka akan tercipta kepuasan. Ketika pelayanan memberikan kesan baik dan adanya peningkatan pelayanan dari pihak pengelola hal ini dapat membentuk rasa puas dan percaya pengunjung terhadap objek wisata Telaga Menjer.

2.Pengaruh Pengalaman Wisatawan Terhadap Kepuasan Wisatawan

Hasil pengujian hipotesis, ditemukan adanya bukti yang menunjukkan bahwa pengalaman wisatawan terhadap kepercayaan wisatawan. Hal ini berarti terdapat hubungan tidak lamgsung antara pengalaman wisatawan terhadap kepercayaan wisatawan. Pengalaman wisatawan mempengaruhi kepercayaan wisatawan dengan melalui kepuasan.

terdapat pengaruh yang signifikan pengalaman terhadap kepuasan wisatawan. Hal ini dapat dibuktikan dengan nilai signifikan yang diperoleh dibawah $\alpha=$ 0,05 yaitu 0,000 . Oleh karena itu hipotesis 2 yang berbunyi ada pengaruh yang signifikan pengalaman wisatawan terhadap kepuasan wisatawan terbukti dan diterima.

Hasil Penelitian ini sesuai dengan pendapat Swastha (2006) tentang pengalaman wisatawan adalah suatu proses, strategi dan implementasi dari suatu perusahaan untuk mengelola konsumen terhadap pengalamannya dengan sebuah produk atau layanan. Kepuasan menurut Westbrook dan Reilly (1983) dalam Tjiptono (2011) adalah respon emosional terhadap pengalamanpengalaman berkaitan dengan produk atau jasa. Sehingga pada dasarnya, pengalaman konsumen adalah penciptaan kepuasan konsumen melalui pengalaman. Selanjutnya, menurut Nasution (2010) faktor yang mempengaruhi kepuasan salah satunya adalah pengalaman masa lalu konsumen ketika menggunakan produk/jasa dari peusahaan maupun pesaingnya. Selain itu hasil penelitian ini sesuai dengan hasil penelitian Ridwan, et al (2015) dimana hasil penelitiannya menemukan bahwa pengalaman wisatawan berpengaruh signifikan terhadap kepuasan wisatawan.

Dapat disimpulkan bahwa pengalaman menjadi kunci keberhasil industri pariwisata, karena pengalaman yang didapatkan wisatawan sangat berpengaruh kepada tingkat kepuasan wisatawan itu sendiri. Saat wisatawan mendapatkan pengalaman yang menyenangkan dan berkesan, maka hal 
tersebut akan berpengaruh baik terhadap tingkat kepuasan wisatawan.

3.Pengaruh Kualitas Layanan Terhadap Kepercayaan Wisatawan

Hasil pengujian hipotesis, ditemukan adanya bukti yang menunjukkan bahwa terdapat pengaruh yang signifikan kualitas layanan terhadap kepercayaan wisatawan. Hal ini dapat dibuktikan dengan nilai signifikan yang diperoleh dibawah $\alpha=$ 0,05 yaitu 0,000 . Oleh karena itu hipotesis 3 yang berbunyi ada pengaruh yang signifikan kualitas layanan terhadap kepercayaan wisatawan terbukti dan diterima.

Hasil Penelitian ini sesuai dengan pendapat Lovelock (1998) dalam Tjiptono (2011) yang mengatakan bahwa kualitas layanan adalah tingkat keunggulan yang diharapkan dan pengendalian atas tingkat keunggulan tersebut untuk memenuhi keinginan wisatawan. Sedangkan Kepercayaan wisatawan adalah ekspektasi dan pengharapan bahwa jasa yang bersangkutan akan memberikan hasil yang positif dan orang lain tidak akan bertindak secara oportunistik, baik secara kata-kata, tindakan, dan kebijakan (Robbins 2011). Dapat disimpulkan bahwa kualitas layanan dapat membentuk kepercayaan wisatawan. Karena pelayanan yang baik akan memberikan kesan serta kepercayaan pada wisatawan. Selain itu penelitian ini sesuai dengan penelitian yang dilakukan kartikasari, dkk (2014) dimana hasil penelitiannya menemukan bahwa kualitas layanan berpengaruh signifikan terhadap kepercayaan wisatawan. Semakin tinggi tingkat kualitas layanan, maka akan semakin tinggi tingkat kepercayaan wisatawan.

4. Pengaruh Pengalaman Wisatawan Terhadap Kepercayaan Wisatawan

Hasil pengujian hipotesis, ditemukan adanya bukti yang menunjukkan bahwa terdapat pengaruh yang signifikan pengalaman wistawan terhadap kepercayaan wisatawan. Hal ini dapat dibuktikan dengan nilai signifikan yang diperoleh dibawah $\alpha=0,05$ yaitu 0,000 . Oleh karena itu hipotesis 4 yang berbunyi ada pengaruh yang signifikan pengalaman wisatawan terhadap kepercayaan wisatawan terbukti dan diterima.

Penelitian ini sesuai dengan pendapatan Costabile (2000) dalam Kartikasari (2011) yang mengatakan bahwa pengalaman konsumen merupakan dasar terciptanya rasa percaya dan akan mempengaruhi evalusi konsumen dalam konsumsi. Constabile dalam Ferrinadewi (2008) juga berpendapat bahwa kepercayaan merupakan persepsi keandalan dari sudut pandang konsumen didasarkan pada pengalamannya, sedangkan faktor dari kepercayaan menurut Tjiptono (2011) terhadap sebuah produk atau jasa merupakan aspek krusial karena kesediaan konsumen untuk mempercayai atau mengandalkan produk/jasa tersebut dan berharap akan menghasilkan sebuah hasil yang baik dan positif. Selain itu penelitian yang dilakukan oleh Pujiastuti, et al (2017) juga menyimpulkan bahwa pengalaman wisatawan berpengaruh positif terhadap kepercayaan wisatawan. Sehingga dapat diyakani, apabila pengalaman wisatawan memiliki kesan yang baik maka berdampak juga pada tingkat kepercayaan wistawan.

5. Pengaruh Kepuasan Wisatawan Terhadap Kepercayaan Wisatawan

Hasil pengujian hipotesis, ditemukan adanya bukti yang menunjukkan bahwa terdapat pengaruh yang signifikan kepuasan wisatawan terhadap kepercayaan wisatawan. Hal ini dapat dibuktikan dengan nilai signifikan yang diperoleh dibawah $\alpha=0,05$ yaitu 0,000 . Oleh karena itu hipotesis 5 yang berbunyi ada pengaruh yang signifikan kepuasan wisatawan terhadap kepercayaan wisatawan terbukti dan diterima.

Kepercayaan menurut Costabile dalam Ferrinadewi (2008) merupakan persepsi keandalan dari sudut pandang konsumen didasarkan pada pengalaman 
atau urutan transaksi atau interaksi yang dicirikan oleh terpenuhinya harapan akan kinerja produk/jasa dan kepuasan. Dapat disimpulkan bahwa kepuasan merupakan sikap yang didasari atas evaluasi (kesimpulan) atau pengalaman masa lalu seseorang dimana pengalaman tersebut mendukung berkembangnya kepercayaan. Selain itu hasil penelitian ini sesuai dengan penelitian Pujiastuti, et al (2017) yang menemukan bahwa kepuasan wisatawan berpengaruh positif terhadap kepercayaan wisatawan.

\section{KESIMPULAN DAN SARAN}

Berdasarkan hasil penelitian seperti yang telah dijelaskan pada bab sebelumnya dapat ditarik kesimpulan yaitu :

1. Ada pengaruh variabel kualitas layanan terhadap kepuasan wisatawan.

2. Ada pengaruh variabel pengalaman wisatawan terhadap kepuasan wisatawan.
Kepuasan menjadi faktor penting bagi pengelola wisata untuk diperhatikan. Hal ini tidak dapat dipungkiri bahwa wisatawan ingin mendapatkan kepuasan setelah mereka mengujungi objek wisata. Wisatawan yang puas pasti akan mempunyai tingkat kepercayaan yang tinggi terhadap objek wisata dibandingkan dengan wisatawan yang tidak puas, sehingga dapat dikatakan bahwa tingkat kepuasan wisatawan sangat menentukan tingkat kepercayaan wisatawan

3. Ada pengaruh variabel kualitas layanan terhadap kepercayaan wisatawan.

4. Ada pengaruh variabel pengalaman wisatawan terhadap kepercayaan wisatawan.

Ada pengaruh variabel kepuasan wisatawan terhadap kepercayaan wisatawan..

\section{DAFTAR PUSTAKA}

Albrubaiee, L., and Al-Nazer, N. (2010). Investigate the impact of relationship marketing orientation on customer loyalty: The customer's perspective. International Journal of Marketing Studies, 2(1), 155-174

Arnett, D. B., and Badrinarayanan, V. (2005). Enhancing customerneeds-driven CRM strategies: Core selling teams, knowledge management competence, and relationship marketing competence. Journal of Personal Selling \& Sales Management, 25 (4), 329343.

Baker, D.A., and Crompton, J.L., 2000. Quality, satisfaction and behavioral intentions. Ann. Tour. Res. 27, 785-804

Canny, I. U. 2013. An Emprical Investigation of Service Quality, Tourist Satisfaction, and Future Behavioral Intentions amog Domestic Local Tourist At Borobudur Temple. International Journal of Trade, Economics and Finance. Vol. 4. No. 2.

Chang, K.-C. (2014). Examining the effect of tour guide performance, tourist trust, tourist satisfaction, and flow experience on tourists' shopping behavior. Asia Pacific Journal of Tourism Research, 19, 219-247. doi:10.1080/10941665.2012.739189 
Crosby, L.A., Evans, K.R.,and Cowles, D., 1990. Relationship quality in services selling an interpersonal influence perspective. J. Mark. 68-81

Darsono. 2008. Hubungan Perceived Service Quality dan Loyalitas : Peran Trust dan Satisfaction sebagai Mediator. The 2nd National Conference UKWMS Surabaya.

Ghozali, I. 2011. Aplikasi Analisis Multivariate Dengan Program SPSS. Semarang: Badan Penerbit Universitas Diponegoro.

Grönroos, C. (1984). A service quality model and its marketing implications. European Journal of Marketing, 18(4), 36-44

Gronroos, C. 2001. Service Management and Marketing, $2^{\text {nd }}$ ed., Wiley, New York, NY. Hirschman, E. C., \& Holbrook, M. B. (1982). Hedonic consumption: Emerging concepts, methods and propositions. Journal of Marketing, 46(3), 92-101. doi: $10.2307 / 1251707$

Judisseno, Rimsky K. 2017. Aktivitas dan Kompleksitas Kepariwisataan. Jakarta: Gramedia Pustaka Utama.

Kartajaya, H. 2007. Hermawan kartajaya on Segmentation. Bandung: PT. Mizan Pustaka.

Karyano. 2008. Kepariwisataan. Jakarta: Grasindo.

Kelly, J. F. 2017. How many or how much? Testing the relative influence of the number of social network risks versus the amount of time exposed to social network risks on post-treatment substance use. . Drug and Alcohol Dependence 175.

Kim, M.-J., Chung, N., and Lee, C.-K. (2011). The effect of perceived trust on electronic commerce: Shopping online for tourism products and services in South Korea. Tourism Management, 32, 256-265. doi:10.1016/j.tourman.2010.01.011

Kotler dan Keller. 2009. Manajemen Pemasaran. Edisi 13. Jakarta: Erlangga.

Machin, D., and Campbell, M.J.. 1989. Statistical Tables for The Design of Clinical Trials, London: Blackwell Scientific Publication.

Meyer, C., and Schwager, A. (2007). Customer experience. Harvard Business Review,1-11.

Morgan, R. and D.Hunt, S. 1994. The Commitment-Trust Theory of Relathionship Marketing. Journal of Marketing. 58 ( 3), 20-38.

Oh, H., Fiore, A. M., and Jeoung, M. (2007). Measuring experience economy concepts: Tourism applications. Journal of Travel Research, 46, 119-132. doi:10.1177/0047287507304039 
Parasuraman, A., Zeithaml, V. A., and Berry, L. L. (1988). SERVQUAL: A multiple item scale for measuring consumer perceptions of service quality. Journal of Retailing, 64(1), 12-37.

Poulsson, S. H., and Kale, S. H. (2004). The experience economy and commercial experiences. The Marketing Review, 4, 267-277.

doi:10.1362/1469347042223445

Pujiastuti, Eny Endah., Umar Nimran, S. Suharyono dan Andriani K. 2017a. The Antecedents of Behavioral Intention Regarding Rural To Tourist Destination. Asia Pacific Journal of Tourism Research. Vol. 22. No. 1.

Pujiastuti, Eny Endah., Umar Nimran, Suharyono, dan Andriani K. 2017b. Study on Destination Image, Satisfaction, Trust, and Behavioral Intention. RJOAS. Vol. 1. No. 61.

Riduan., Suharyono, Achmad Fauzi, dan Darminto. 2015. The Effect of Tourism Service Quality, Tourist Destination Image and Experience of Tourist towards Tourists Satisfaction, Tourism Word of Mount, Tourist Destination Preferences, and Tourist Destination Loyalty. European Journal of Business and Management. Vol. 7. No. 2.

Stamboulis, Y., and Skayannis, P. (2003). Innovation strategies and technology for experience-based tourism. Tourism Management, 24(1), 35-43.

Tjiptono, F. 2011. Service, Quality and Satisfaction. Yogyakarta: Andi Offset.

Tjiptono, F. 2011. Pemasaran Jasa. Malang: Bayumedia Publishing.

Urban, G. L., Sultan, F., and Qualls, W. J. (2000). Placing trust at the center of your Internet strategy. MIT Sloan Management Reviews, 42(1), 39-48. 